\title{
Editorial
}

\section{Design Learning for Tomorrow - Design Education from Kindergarten to PhD}

This issue of FORMakademisk is built upon papers from the DRS//CUMULUS Oslo 2013 conference - 2nd International Conference for Design Education Researchers — at Oslo and Akershus University College of Applied Sciences (HIOA) 14-17 May 2013 in Oslo. The conference was a cooperative event between the Design Research Society (DRS) and the International Association of Universities and Schools of Design, Art and Media (CUMULUS), and hosted by the Faculty of Technology, Art and Design at HIOA. The theme for the conference was Design Learning for Tomorrow - Design Education from Kindergarten to $P h D$. The conference received an overwhelming response both ahead of the conference, with 225 admitted papers, and during the conference with 280 delegates from 43 countries listening to 165 presentations and having a good time in Oslo. The last day of the conference was the $17^{\text {th }}$ of May, Norway National Day, with traditional songs and a children's parade in the centre of Oslo.

We see this positive response to the conference as a growing awareness of perceiving design in a broad interdisciplinary perspective in support for a better tomorrow. For years the Design Literacy Research Group, with a base at HIOA in Oslo, has promoted the idea that sustainable design solutions should include more than 'professional' designers; they should also include the general public as 'conscious' consumers and decision makers with responsibility for quality and longevity, as opposed to a 'throw-away' society.

This is also the reason why the conference focused on design education from Kindergarten to $\mathrm{PhD}$. This perspective was put forward as a contrast to most design education conferences where there is either a focus on design education for professionals or general education for children and non-designers. In the call for conference papers, we argued for a longitudinal perspective on design education where the education of professional designers is seen in relation to the general education of the public. This is becoming increasingly relevant as more decisions are being made on the basis of visual representations. We regard education at many different levels as important in securing a sustainable future for the design of everyday life solutions. For that, we need qualified and reflective decision makers with a consciousness for quality of design and solutions.

Why have these issues of concern been so important for Norwegian researchers within this field? The answer goes back to the 1960 National Curriculum for primary and lower secondary schools in Norway, when art and crafts were merged into one subject. Currently, this subject includes art, architecture, design and visual communication. No other Nordic-or European - country seems to have developed a model similar to this. Today, we see the benefit of this merger where design is at the core of the subject for youngsters - building upon the best from art and the best from craft to become creative problem solvers and critical consumers. Hopefully we will soon see UNESCO or other organizations with responsibility for funding research recognize that we need more research and knowledge on what impacts design education from Kindergarten to $\mathrm{PhD}$ have on consumer habits and sustainable development at large. We hope that such projects are not far off. Politicians have for too long been told that advanced mathematics is the main way to stimulate youngsters to abstract thinking. The designerly way of solving problems can be even more suitable in training abstract thinking, and it will also include ethical aspects of sustainable development and ecology. A design literate general public would therefore be a step forward in supporting the statement of com- 
mitment for sustainable development by the members of CUMULUS - the 'Kyoto Design Declaration 2008' (Cumulus, 2008).

In the conference proceedings the conference chair professor Liv Merete Nielsen wrote:

\begin{abstract}
We hope, as the organizers, that the conference will promote design and design education as a field of practice and inquiry. We hope that it will create a fertile context for establishing new networks of future cooperation, nationally and internationally, and that design education research in its broad context will be recognized both inside and outside the design research community. The general public's interest for design and quality is developed from the kindergarten, through primary and secondary education and the public's attitude is central for professional activities and a broad democratic design participation (Nielsen, 2013, p. iii).
\end{abstract}

Now, in 2015, we can see that this conference has been a further step to international collaboration in design education research. Guest researchers have visited HIOA and a new international research consortium has been created. Other academic journals have followed up the conference theme with special issues, such as Art, Design \& Communication in Higher Education, TechneA, Design and Technology Education and Studies in Material Thinking. The role of these journals is essential for the advancement of knowledge production within the design education field. This issue of FORMakademisk contains articles developed on the basis of the conference. They represent a wide perspective on design education at different levels.

\title{
Articles in this Issue
}

Pino Trogu, professor at San Francisco State University, discusses in the article Working memory and background knowledge: Cognitive science in the design classroom two universal principles from cognitive psychology and proposes some ways in which those principles relate to graphic design. The two most important principles are first, the strict constraints of working memory, a function that persists for only a few seconds, and second, the finding that perceptions and meanings are mediated by the cultural knowledge of viewers, including their knowledge of design conventions and genre. Better designs are likely to emerge from the designer's familiarity with these psychological and cultural principles. Visual examples, including maps and student projects, illustrate how the two principles are useful for classroom instruction.

Eva Lutnaes, postdoc at the Oslo and Akershus University College of Applied Sciences explores in her article Imagining the unknown. Responsible creativity for a better tomorrow the scientific discourse on creativity in the field of design education. She draws upon 165 papers presented at the DRS//CUMULUS Oslo 2013 conference. The review shows creativity to be a key concept in scientific discourse and identifies five storylines that conceptualise creativity as a generic human capacity for which the field of design education eagerly claims responsibility. In scientific discourse, the fostering of creativity is a leading motive when articulating reasons for design to gain terrain in general education. A multifaceted repertoire of strategies to solve design problems can drive new ideas or artefacts that contribute to both environmental protection and degradation, human aid or human-made disasters. How to frame the relevant educational content of creativity as part of a general education that empowers citizens to promote sustainability and meet global challenges ahead is discussed.

Joanna Boehnert, visiting research fellow at the University of Colorado and director of EcoLabs, develops in her article Ecological literacy in design education: A theoretical introduction theoretical aspects on ecological literacy for design education. Ecological literacy is a concept developed by sustainability educators that provides a basis for learners to 
understand the nature of environmental problems and to develop new capacities and critical skills to respond effectively. The article gives a philosophical overview of why ecological literacy is necessary, describes ecological principles with associated design concepts and explains why critical ecological literacy is necessary to make the work of transforming unsustainable conditions and designing sustainable ways of living possible.

Robert Harland, lecturer at Loughborough University, asks in his article Testing keywords internationally to define and apply undergraduate assessment standards in art and design: What language should be featured in assessment standards for international students? Have universities adjusted their assessment methods sufficiently to match the increased demand for studying abroad? How might art and design benefit from a more stable definition of standards? Language use is at the heart of this issue, yet it is generally overlooked as an essential tool that links assessment, feedback and action planning for international students. The paper reveals existing and new data that build on research since 2009, aimed at improving students' assessment literacy. Recommendations are offered to stimulate local and global discussion about keyword use for defining undergraduate assessment standards in art and design.

Aysar Ghassan, senior lecturer at Coventry University, and Erik Bohemia, senior lecturer at Loughborough University, present in the article The Global Studio: Incorporating peer learning into the design curriculum, research on a specific learning environment named the Global Studio. The Global Studio aims to provide students with peer-learning experiences, conducted through complex project situations. The Global Studio makes use of a blended learning approach, a combination of online learning and face-to-face teaching. The learning environment of The Global Studio is described as operationally different from tutor-led design education as lecturers are more 'distant' in teaching and learning activities. In recognition of the benefits of peer learning, the authors have designed explicit opportunities for peer tutoring to take place within Global Studio Projects. The authors conclude by arguing that in order to maximise the benefits of student-led projects featuring peer tutoring, activities that facilitate student-led learning, need to be scaffolded into design programmes.

Matthew Watkins, PhD and senior lecturer at Nottingham Trent University, presents in the article An audio visual approach to the teaching of the social aspects of sustainable product design research on approaches that enhance understanding on the complexity of the social aspects in sustainable design. The study indicates that audio visual introductions in combination with collaborative learning are beneficial to foster learning among students from what is described to be the Net Generation. The workshops in this study aimed to enable students to grasp the complexity of the social aspects of sustainable design in a short space of time and to encourage personal responses and creative problem solving through an exploration of design-thinking solutions.

Meryem Yalcin, assistant professor at TOBB University of Economics and Technology in Ankara, Turkey, discusses in the article Progressive development of creative design skills from kindergarten education how early childhood is a beneficial period for development of creative-thinking skills and how this development may be facilitated in kindergarten. Yalcin argues that kindergarten environments where children imagine, create, practice, modify, recognise, manipulate and share knowledge, experiences and objects through play are ideal for facilitating learning on creative-thinking skills. These basic skills, which children develop in kindergarten, should be further developed through the entire education.

Astrid Skjerven, $\mathrm{PhD}$ and professor at the Oslo and Akershus University College of Applied Sciences, presents in her article Vernacular traditions in Norwegian jewellery design: Past, present, future how the capability of communicating identity has become of greater importance. The paper sheds light on the relation between Norway's role in the global scene and the use of the vernacular tradition in the development of jewellery design in 
general. It consists of a historical exploration that leads to a discussion of the present and future situation. Today there is a cleft between consumer behaviour and avant-garde practice. In accordance with the global situation and Norway's geopolitical position in the outskirts of political and economic decisions, the setting is characterized by a variety of practices and by a slow acceptance of the vernacular values in a world of avant-garde practitioners.

Oslo/Volda, June 2015

Liv Merete Nielsen

Section Editor

Karen Brænne

Special Issue Editor
Ingvill Gjerdrum Maus

Special Issue Editor

\section{Liv Merete Nielsen}

Professor, Dr. ing.

Faculty of Technology, Art and Design

Oslo and Akershus University College of Applied Sciences

Email address: livmerete.nielsen@hioa.no

\section{Karen Brænne}

Associate Professor, PhD

Faculty of Art and physical

Volda University College

Email address: karenb@hivolda.no

Ingvill Gjerdrum Maus

PhD-candidate

Faculty of Technology, Art and Design

Oslo and Akershus University College of Applied Sciences

Email address: ingvillg.maus@hioa.no 


\section{References}

Cumulus. (2008). Kyoto Design Declaration 2008, Kyoto. http://cumulusassociation.org/images/stories/Current affairs files/kyoto design declaration2008.pdf

Nielsen, Liv Merete. (2013). Design Learning for Tomorrow. Design Education from Kindergarten to PhD. In Janne Beate Reitan, Peter Lloyd, Erik Bohemia, Liv Merete Nielsen, Ingvild Digranes \& Eva Lutnæs (Eds.), Design Learning for Tomorrow. Design Education from Kindergarten to PhD. Proceedings from the 2nd International Conference for Design Education Researchers, 14-17 May 2013 (Vol. 1, pp. i-iii). Oslo: ABM-media.

\section{Links for more information on the DRS//CUMULUS Oslo 2013 conference}

Official webpage for the DRS//CUMULUS Oslo 2013 conference

http://www.hioa.no/DRScumulus

\section{Reviews from the conference}

http://www.cumulusassociation.org/component/content/1486-drscumulus-oslo-2013-2nd-internationalconference-for-design-education-researchers/152

http://www.hioa.no/eng/Aktuelle-saker/Successful-DRS-CUMULUS-conference

\section{Pictures from the conference}

http://www.hioa.no/eng/About-HiOA/Faculty-of-Technology-Art-and-Design/DRS-CUMULUS-Oslo2013/Pictures-from-the-DRS-CUMULUS-Oslo-2013-Conference

\section{Book of abstracts}

http://issuu.com/erik.bohemia/docs/book of abstract_drs cumulus_oslo_ 2

\section{Conference proceedings}

Volume 1

http://www.academia.edu/8995210/Design Education from Kindergarten to PhD Design Learning for Tom orrow Proceedings of the 2nd International Conference for Design Education Researchers Vol. 1

Volume 2

http://www.academia.edu/8995299/Design Education from Kindergarten to PhD Design Learning for Tom orrow Proceedings of the 2nd International Conference for Design Education Researchers Vol. 2

Volume 3

http://www.academia.edu/8995358/Design_Education_from_Kindergarten_to_PhD_Design_Learning_for_Tom orrow_Proceedings_of the 2nd_International_Conference_for_Design_Education_Researchers_Vol._3

Volume 4

http://www.academia.edu/8995546/Design_Education_from_Kindergarten_to_PhD_Design_Learning_for_Tom orrow_Proceedings_of_the_2nd_International_Conference_for_Design_Education_Researchers_Vol._4 